\title{
Distributional patterns of the Neotropical genus Thecomyia Perty (Diptera, Sciomyzidae) and phylogenetic support
}

\author{
Amanda Ciprandi Pires ${ }^{1,2} \&$ Luciane Marinoni1 ${ }^{1,3}$
}

\begin{abstract}
${ }^{1}$ Laboratório de Estudos em Syrphidae e Sciomyzidae Neotropicais, Departamento de Zoologia, Universidade Federal do Paraná, Caixa Postal 19020 , 81531-980 Curitiba-PR, Brasil.

${ }^{2}$ Bolsista do CNPq (Doutorado), Programa de Pós-Graduação em Entomologia. amandaciprandi@yahoo.com.br

${ }^{3}$ Pesquisador do CNPq.
\end{abstract}

\begin{abstract}
Distributional patterns of the Neotropical genus Thecomyia Perty (Diptera, Sciomyzidae) and phylogenetic support. The distributional pattern of the genus Thecomyia Perty, 1833 was defined using panbiogeographic tools, and analyzed based on the phylogeny of the group. This study sought to establish biogeographical homologies in the Neotropical region between different species of the genus, based on their distribution pattern and later corroboration through its phylogeny. Eight individual tracks and 16 generalized tracks were identified, established along nearly the entire swath of the Neotropics. Individual tracks are the basic units of a panbiogeographic study, and correspond to the hypothesis of minimum distribution of the organisms involved. The generalized tracks, obtained from the spatial congruence between two or more individual tracks, are important in the identification of smaller areas of endemism. Thus, we found evidence from the generalized tracks in support of previous classification for the Neotropical region. The Amazon domain is indicated as an area of outstanding importance in the diversification of the group, by the confluence of generalized tracks and biogeographic nodes in the region. Most of the generalized tracks and biogeographical nodes were congruent with the phylogenetic hypothesis of the genus, indicating support of the primary biogeographical homologies originally defined by the track analysis.
\end{abstract}

KEYWORDS. Areas of endemism; diversification; panbiogeography; phylogeny; Tetanocerini.

RESUMO. Padrões de distribuição do gênero Neotropical Thecomyia Perty (Diptera, Sciomyzidae) e suporte filogenético. O padrão distribucional do gênero Thecomyia Perty, 1833 foi definido usando ferramentas pan-biogeográficas, e analisado com base na filogenia do grupo. O presente estudo buscou o estabelecimento de homologias biogeográficas na região Neotropical entre as diferentes espécies do gênero, com base em seu padrão de distribuição e posterior corroboração por intermédio de sua filogenia. Foram obtidos oito traços individuais e 16 traços generalizados, estabelecidos ao longo de praticamente toda região Neotropical. Os traços individuais são a unidade básica de um estudo pan-biogeográfico, correspondendo à hipótese mínima de distribuição dos organismos em questão. Os traços generalizados, obtidos a partir da congruência espacial entre dois ou mais traços individuais, são importantes no reconhecimento de áreas de endemismo menores. Assim, houve suporte para classificação prévia na região Neotropical a partir dos traços generalizados obtidos. O domínio Amazônico foi indicado como área de importância destacada na diversificação do grupo pela confluência de traços generalizados e nós biogeográficos na região. Parte considerável dos traços generalizados e nós biogeográficos foram congruentes com a hipótese filogenética do gênero, indicando suporte das homologias biogeográficas primárias definidas inicialmente pela análise de traços.

PALAVRAS-CHAVE. Áreas de endemismo; diversificação; filogenia; pan-biogeografia; Tetanocerini.

Thecomyia Perty, 1833 is a neotropical genus of the family Sciomyzidae, more commonly known as "snail-killing flies." The included species occur in Central and South America, and some are more common than others (Knutson \& Carvalho 1989). In Marinoni \& Mathis' (2000) phylogenetic analysis, Thecomyia is related to Ethiolimnia Verbeke, 1950 (distributed in Afrotropical region), Teutoniomyia Hennig, 1952 (Neotropical region), Sepedoninus Verbeke, 1950 (Afrotropical region), Sepedonella Verbeke, 1950 (Afrotropical region), Sepedon Latreille, 1804 (Neartic, Paleartic, Neotropical, Afrotropical, Oriental, Australian), Sepedomerus Steyskal, 1973 (Neotropical and Oriental) and Sepedonea Steyskal, 1973 (Neotropical), forming a monophyletic group that is referred to as the Sepedon group.

There is a paucity of information on the biology of Thecomyia, with published records being limited to
Thecomyia limbata (Wiedemann, 1819). Larvae of this species are predaceous on freshwater, non-operculate snails (Abercrombie \& Berg 1975), like most species of Sepedon, Sepedonea and Sepedomerus (Neff \& Berg 1966; Marinoni \& Mathis 2000). On the other hand, the taxonomy and phylogenetic relationships of Thecomyia species have been recently studied, facilitating biogeographic analysis of the genus (Marinoni et al. 2003).

Twelve species have been described in Thecomyia: $T$. longicornis Perty, 1833 [type species of the genus]; T. lateralis (Walker, 1858); T. limbata (Wiedemann, 1819); T. abercrombiei Marinoni \& Steyskal, 2003; T. autazensis Marinoni \& Steyskal, 2003; T. bonattoi Marinoni \& Steyskal, 2003; T. chrysacra Marinoni \& Steyskal, 2003; T. mathisi Marinoni \& Steyskal, 2003; T. naponica Marinoni \& Steyskal, 2003; T. papaveroi Marinoni \& Steyskal, 2003; T. signorelli Marinoni \& Steyskal, 
2003 and T. tricuneata Marinoni \& Steyskal, 2003. According Marinoni et al. (2003) these species constitute a monophyletic group (Fig. 1). The geographic distribution of clade 1 (Fig. 1) is mainly Central American, from Guatemala to Brazil (São Paulo). The clade formed by T. autazensis, T. papaveroi and $T$. naponica occurs along the Equator in Ecuador and Brazil (Pará and Amazonas), while clade 3 (Fig. 1) is found from Panama to southern Brazil (Santa Catarina). In Sciomyzidae, only the genus Sepedonea has been studied in a biogeographical context (Pires et al. 2008), indicating the need of biogeographical studies for the family.

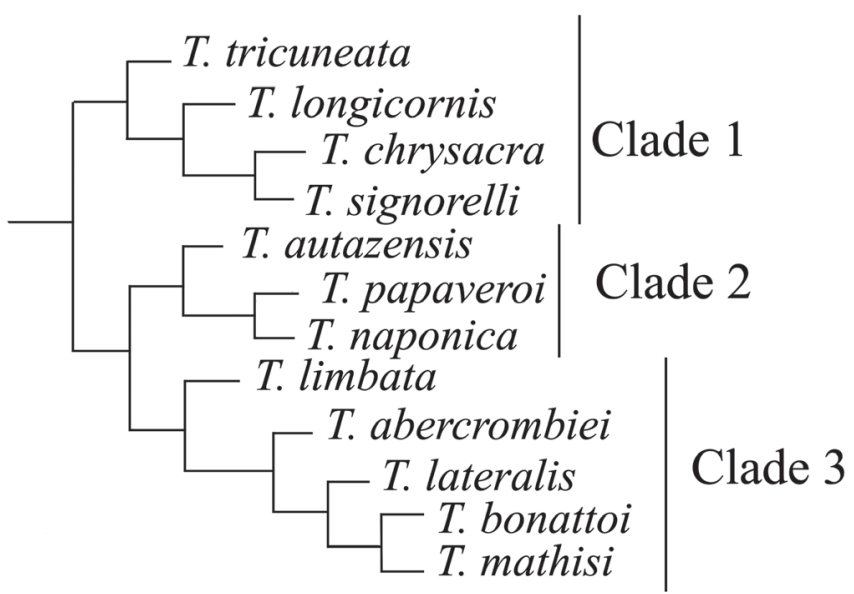

Fig. 1. Phylogenetic analysis for Thecomyia species (modified from Marinoni et al. 2003).

Panbiogeography, as proposed by Croizat (1958, 1964), emphasizes the importance of the spatial dimension of biodiversity in order to understand evolutionary patterns and processes (Craw et al. 1999). It is accepted among the basic methodologies that make up the branch of historical biogeography (Morrone \& Crisci 1995; Morrone 2005) and it is currently characterized by the admission of more than one approach (Morrone 2005). One of these is known as track analysis (Craw et al. 1999), and it is utilized in the present study.

Track analysis can provide useful information through the generation of individual and generalized tracks, as well as biogeographical nodes. Generalized tracks are important in the recognition of smaller areas of endemism, which can be classified hierarchically into an orderly biogeographical system (districts, provinces, domains, subregions, and biogeographic realms) (Morrone 2001a, 2006). Although many consider the areas of endemism to be simply operating units, representative of the distribution, the most appropriate definition takes into account the historical character involved in their determination. More than just operating units, areas of endemism are essentially historical entities signifying key elements in understanding evolution (Harold \& Mooi 1994; Morrone 2001a). This emphasizes the need for these smaller historical units to be based on an evolutionary perspective.
Morrone (2001a) stressed the importance of an integrative view in biogeographic practice and recommended the reconciliation of different methodologies, used for recognition and support of biogeographic homologies. In this sense, panbiogeography comprises a first step in the recognition of primary biogeographical homologies, followed by confirmation of these cases in secondary homologies by analysis of cladistic biogeography (Morrone 2001a). The primary biogeographical homologies correspond to assumptions about common biogeographical history, inferred by matching patterns of distribution, which in track analysis correspond to the generalized tracks (Morrone 2001a).

Thus, the goal of this study is to analyze the distributional patterns of the included species using the method of track analysis to recognize primary homologous areas within the Neotropical region (Morrone \& Crisci 1995; Morrone 2001a, 2004, 2006). The present study will not apply any additional biogeographic methodology other than the panbiogeographic tools (Morrone \& Crisci 1995). The discussion, however, will be sustained on the basis of the phylogenetic relationships among Thecomyia species (Marinoni et al. 2003). This association aims at the identification of historically supported areas of endemism according to the genus phylogeny (Nihei \& Carvalho 2005; Pires et al. 2008).

\section{MATERIAL AND METHODS}

Track analysis is characterized by the evaluation of the geographical scope of the organisms involved, at which point patterns can be recognized that imply spatial homology (Craw et al. 1999). In a first step, individual tracks are defined by plotting the distributional points of each species on a map and connecting these points by a line representing the minimum geographical distance between each pair of points (Morrone \& Crisci 1995). Accordingly, the spatial component of Thecomyia species is hypothesized (Morrone 2001b).

Generalized tracks are established where there is spatial congruence (overlap) among individual tracks. They can indicate areas of endemism, as already stated, since areas of endemism are, minimally, the congruence in distributions of two or more species (Platnick 1991). Given that any amount of overlap distributions suggests at least an individual hypothesis of historical commonality (Harold \& Mooi 1994), they can also indicate the pre-existence of ancestral biotic components that have been fragmented by tectonic or climatic changes (Croizat 1958, 1964; Morrone \& Crisci 1995; Morrone 2004). In fact, these tracks can provide a spatial criterion for biogeographical homology, indicating the existence of smaller area of endemism which can be ordered into a hierarchical biogeographical classification system, especially when they are consistent with panbiogeographical patterns previously established by other taxa in a given area (Morrone \& Crisici 1995; Contreras et al. 2001; Morrone 2004, 2006).

Biogeographical nodes are complex areas defined by the intersection of two or more generalized tracks (Craw et al. 
1999; see also Heads 2004). Recognizing the nature of a node is a complex task (Heads 2004). They may exhibit one or several significant biological characteristics (Craw et al. 1999). Nodes may indicate the hybrid character of the area composed of different ancestral geological and biotic fragments that were intermingled in space and time (Crisci et al. 2003). In this sense, they can represent important biodiversity hotspots (Grehan 1993) occupied by biotic elements with different origins (Morrone \& Crisci 1992; Prevedello \& Carvalho 2006). When they are supported by previously published phylogenies, these may also indicate, together with generalized tracks, that the studied organisms are not randomly arranged, but share a common spatial and temporal evolutionary context (Nihei \& Carvalho 2005).

All these procedures were implemented using software ArcView 3.2 (Esri 1998). Reconstruction of the individual and generalized tracks was performed manually. The phylogeny of Thecomyia species was then used in seeking support for biogeographical homologies initially established by panbiogeography (Nihei \& Carvalho 2005). A generalized track consisting of the overlap in the distributional pattern of phylogenetically related species would confirm the historical identity of the concerned area. The location of generalized tracks were also compared to the areas of endemism scheme proposed by Morrone (2006), to determine whether they were located within its subregions. The strict congruence between tracks and subregions provides support for the proposed classification. This scheme was used because it is considered a more explanatory proposal for the distribution patterns of the region. Given that his proposition involved both humid and dry environments, more features of the region are covered by the classification (Nihei \& Carvalho 2007; Sigrist \& Carvalho 2009).

Distributional data of Thecomyia species were obtained from available literature (Marinoni et al. 2003; Rede SpeciesLink 2008) and then analyzed. Thecomyia autazensis, T. bonattoi, T. naponica and T. tricuneata are known from single localities.

\section{RESULTS AND DISCUSSION}

Eight individual tracks were obtained from the available geographical data of Thecomyia (Figs. 2, 3). The species $T$. autazensis, T. bonattoi, T. naponica and T. tricuneata did not constitute individual tracks, since they have a restricted distributional pattern, with only one available collection location (see distribution data of each species available in Appendix). The individual track establishment is important, representing the basic unit of a panbiogeographic study. They represent the space where evolution occurs (Contreras-Medina et al. 2001; Morrone 2001b) and indicate the distribution of the studied organisms (Morrone 2001b).

The genus and therefore its tracks were exclusively neotropical in distribution, with the northernmost point limited by T. chrysacra (Guatemala, La Providencia) and the southernmost point by T. lateralis (Brazil, Florianópolis) (Fig. 2).

Revista Brasileira de Entomologia 55(1): 6-14, março 2011
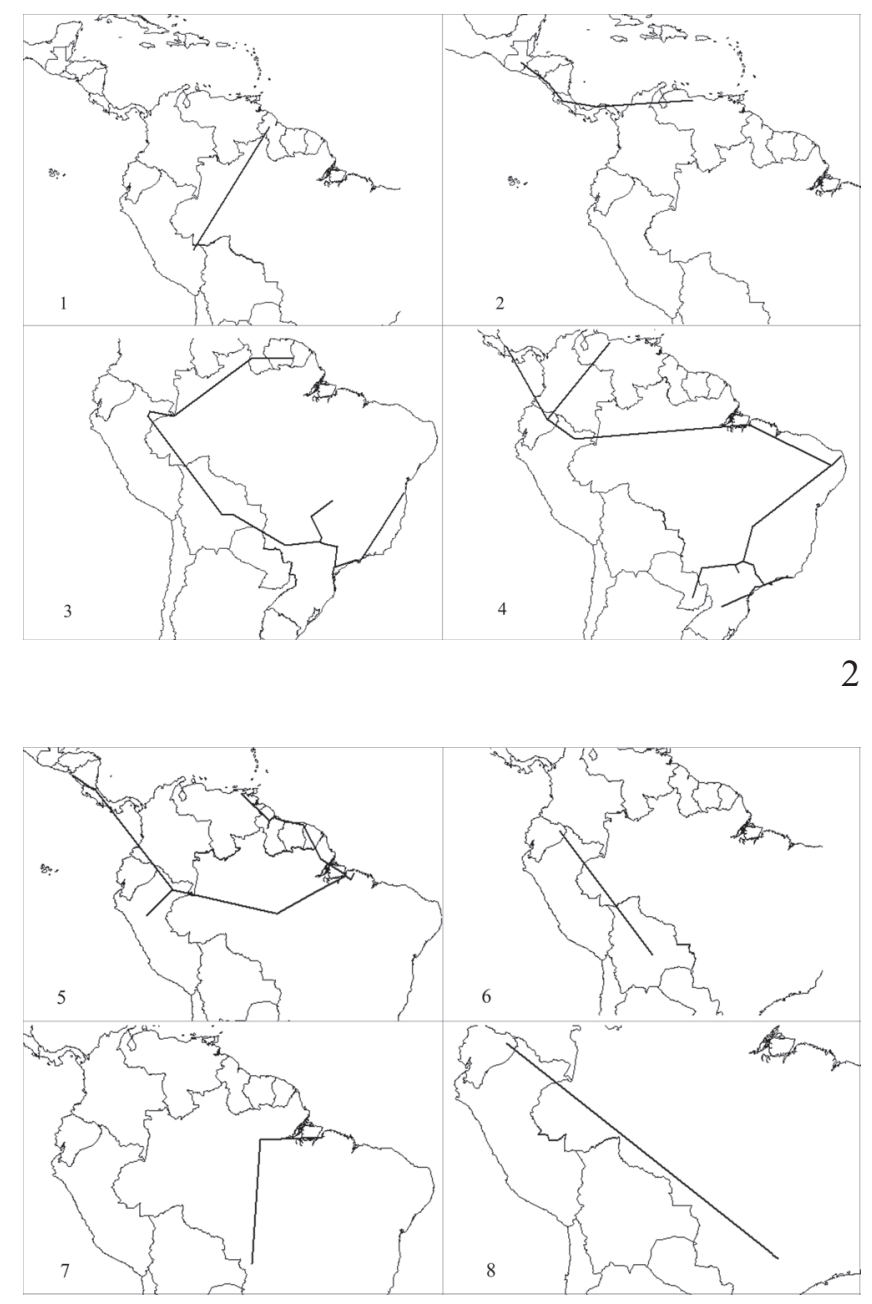

3

Figs. 2-3. 2, Individual tracks obtained for species of Thecomyia: $1-T$. abercrombiei; $2-$ T. chrysacra; $3-$ T. lateralis; $4-$ T. limbata; 3 , individual tracks: $5-$ T. longicornis; $6-$ T. mathisi $; 7-$ T. papaveroi $; 8-$ T. signorelli.

Based on overlapping of individual tracks, 16 generalized tracks were generated (Fig. 4). This overlapping in distributions was interpreted as primary biogeographical homologies in the Neotropical region (Morrone 2001a), as previously discussed.

Considering the biogeographic scheme proposed by Morrone (2006) for the Neotropics, there were three generalized tracks located into the Parana subregion (Morrone 2006), one generalized track located between the Parana and Chacoan subregions, ten generalized tracks in the Amazonian subregion and two generalized tracks characteristics of the Caribbean subregion (for discussion of these biogeographical areas, see Morrone 2006) (Fig. 4). The biogeographic provinces and the taxa associated with each generalized track are presented in Table I.

The distributional pattern obtained for the genus was shown to be congruent to the proposed classification of the Neotropical region (Morrone 2006) (Figs. 4, 5). In this classification, the biotic components characterized for the region 


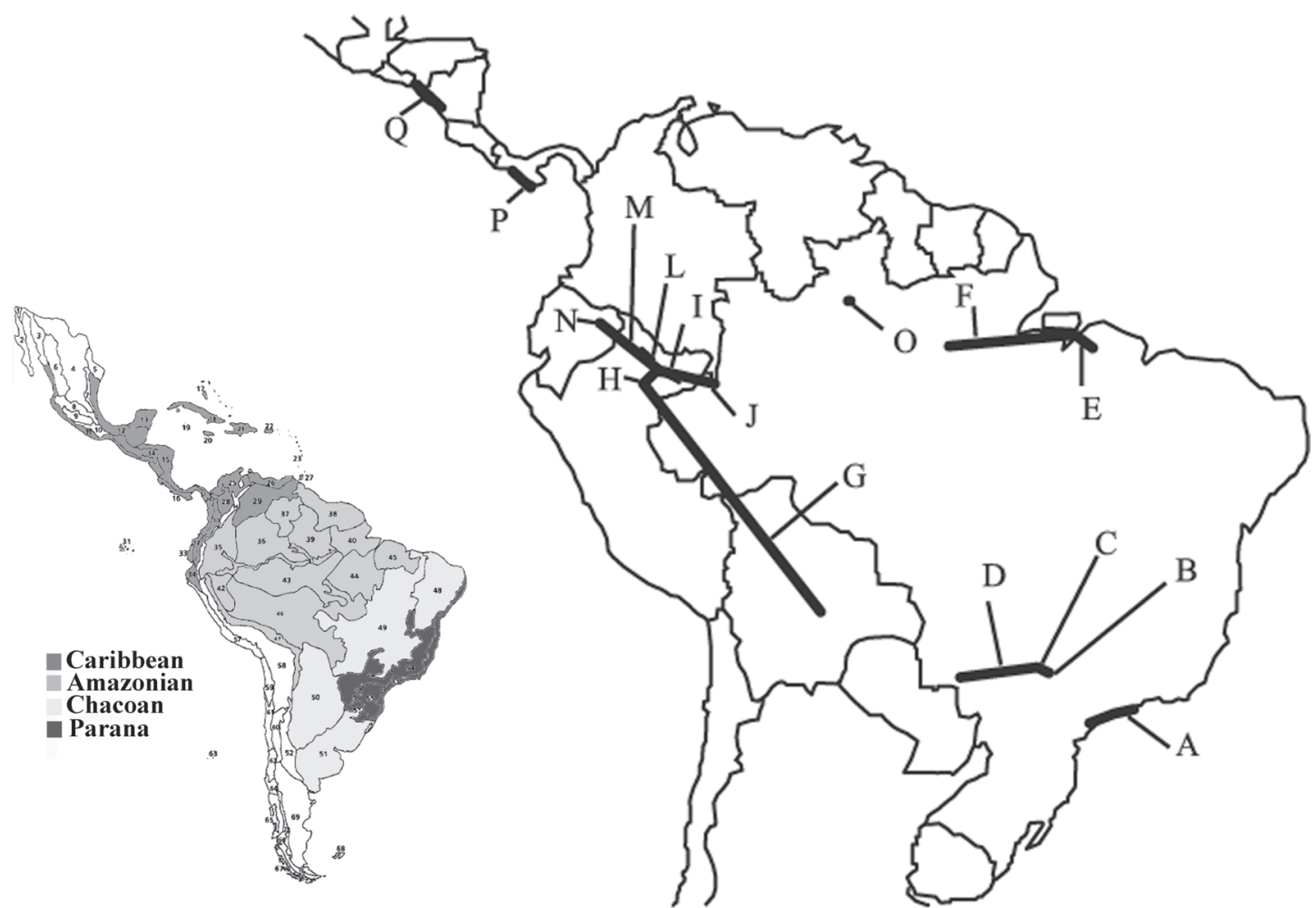

Fig. 4. Thecomyia generalized tracks (A-Q) and Neotropical biogeographic pattern proposed by Morrone (2006) (see text for discussion).

Table I. Generalized tracks and their respective locations and associated taxa.

\begin{tabular}{|c|c|c|c|}
\hline Generalized tracks & Biogeographic provinces & Neotropical subregion & Taxa associated \\
\hline A & Brazilian Atlantic Forest & Parana & T. lateralis and T. limbata \\
\hline $\mathrm{B}$ & Parana Forest & Parana & T. lateralis and $T$. signorelli \\
\hline $\mathrm{C}$ & Parana Forest & Parana & T. lateralis, T. limbata and T. signorelli \\
\hline $\mathrm{D}$ & Parana Forest province to Cerrado province & Parana and Chacoan & T. lateralis and T. limbata \\
\hline $\mathrm{E}$ & Varzea and Madeira & Amazonian & T. limbata and T. longicornis \\
\hline $\mathrm{F}$ & Amapa, Maderia, Tapajos-Xingu and Para & Amazonian & T. limbata and T. papaveroi \\
\hline G & Varzea, Madeira, Pantanal and Yungas & Amazonian & T. lateralis and T. mathisi \\
\hline $\mathrm{H}$ & Varzea & Amazonian & T. lateralis and $T$. longicornis \\
\hline I & Madeira province to Varzea province & Amazonian & T. lateralis, T. longicornis and T. signorelli \\
\hline $\mathrm{J}$ & Madeira & Amazonian & T. lateralis and $T$. longicornis \\
\hline $\mathrm{L}$ & Varzea province to Napo province & Amazonian & T. limbata, T. signorelli and T. longicornis \\
\hline M & Napo & Amazonian & T. limbata and T. signorelli \\
\hline $\mathrm{N}$ & Napo & Amazonian & T. mathisi, T. limbata and T. signorelli \\
\hline $\mathrm{O}$ & Roraima & Amazonian & T. abercrombiei and T. lateralis \\
\hline $\mathrm{P}$ & Western Panamanian Isthmus & Caribbean & T. longicornis and T. limbata \\
\hline Q & Western Panamanian Isthmus & Caribbean & T. chrysacra and $T$. longicornis \\
\hline
\end{tabular}

were defined based on overlapping biogeographical patterns of taxa that were not necessarily related (Morrone 2001b). Thus, the generalized tracks found for Thecomyia species herein corroborate this classification that divides the Neotropical region into four endemic subregions (Fig. 5).
The same support for this Neotropical classification was also observed by Pires et al. (2008) based on Sepedonea distribution, as well as by Morrone (2003) and Nihei \& Carvalho (2005), who analyzed decapods of the family Trichodactylidae and the species of Polietina (Diptera, Muscidae) respectively. 
The congruence of these patterns in a given area is of fundamental importance for understanding their evolution (Morrone 2006). Under the panbiogeographic assumption that the earth and life evolve together (Croizat 1958, 1954), it is possible to interpret this congruence as indicative of a common history of the taxa in the area, underscoring the historical identity of the places (Morrone 2006).

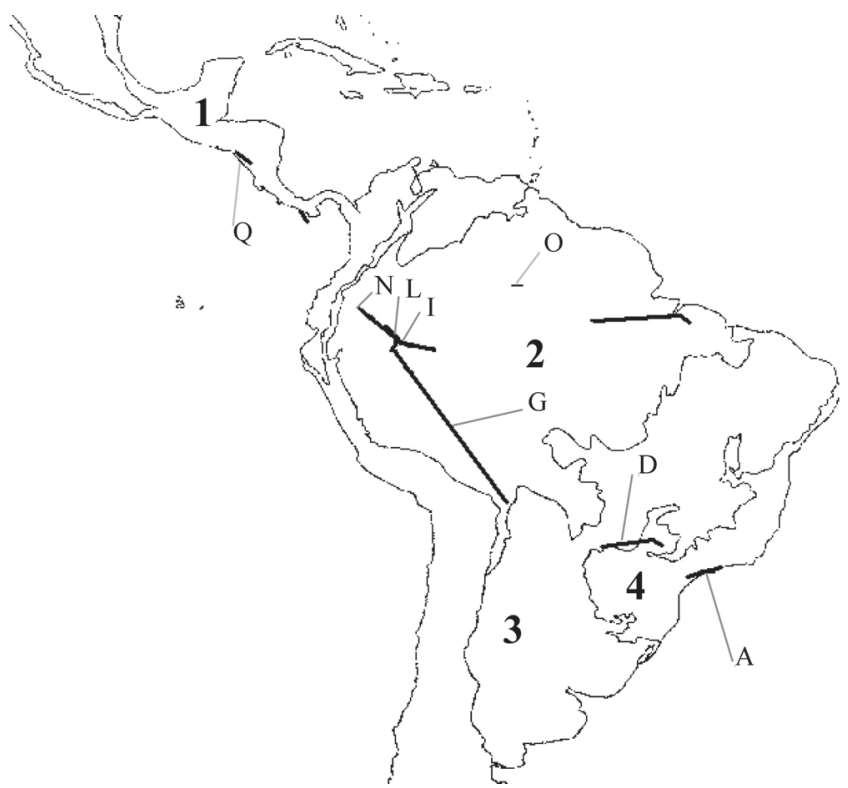

Fig. 5. Generalized tracks of Thecomyia on the map of Neotropical region (obtained from Morrone 2001b). 1 - Caribbean subregion; 2 -Amazonian subregion; 3 - Chacoan subregion and 4 - Parana subregion. Letters correspond to phylogeny-supported tracks.

The 16 primary statements of biogeographic homology for the Neotropical region were contrasted with Thecomyia's phylogeny and it aimed to investigate phylogenetic (historical) support for the concerned area (Fig. 6). The obtained generalized tracks show congruence with the phylogenetic relationship presented for Thecomyia (Marinoni et al. 2003). Once a generalized track is supported by the species phylogeny, an endemic area indicating the possible pre-existence of an ancestral biota for the concerned species is corroborated (Nihei \& Carvalho 2005). Evidence of pre-existence of an ancestral biota can be observed in track A, comprising two phylogenetic related species (T. lateralis and T. limbata) (Fig. 6). Similarly, the same kind of inference can be obtained from the remaining phylogeny-supported tracks. Tracks C and D also comprise these related species, while track $\mathrm{G}$ encompasses T. lateralis and T. mathisi, which form one of the clades of Thecomyia's phylogeny. Tracks I and L are also supported by the related species, T. longicornis and T. signorelli. The species T. mathisi and T. limbata are present on track $\mathrm{N}$ and finally, track $\mathrm{O}$ is formed by T. abercrombiei and T. lateralis, while track $\mathrm{Q}$ by the phylogenetic related species, T. chrysacra and T. longicornis (Fig. 6). Therefore, these phylogeny-sup- ported tracks can be corroborated as areas of endemism for the concerned species. For example, track $\mathrm{G}$ comprising the phylogenetic related species T. mathisi and T. lateralis probably indicates a historical area, important for the diversification context of these species.

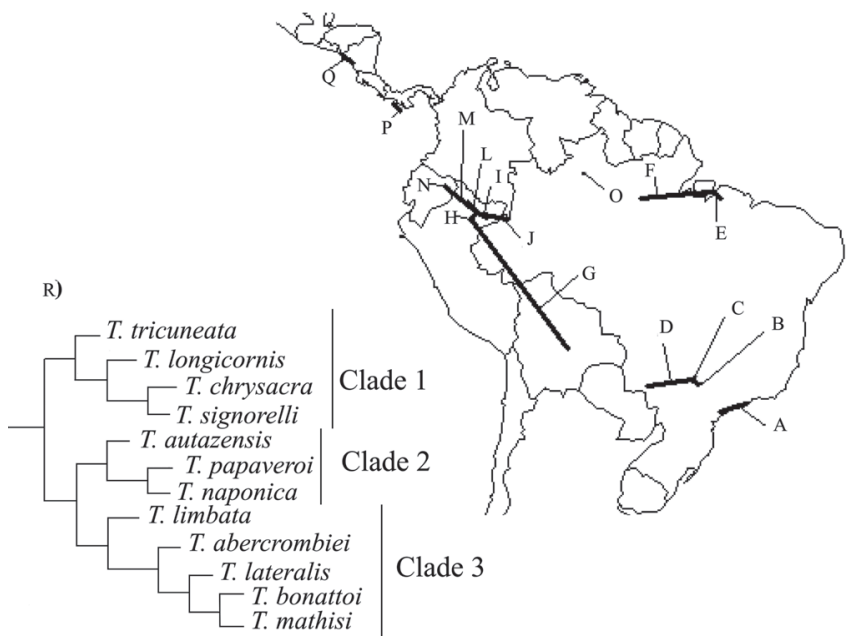

Fig. 6. Thecomyia generalized tracks $(\mathrm{A}-\mathrm{Q})$ and previously established phylogenetic analysis for the species in the genus $-\mathrm{R}$ (modified from Marinoni et al. 2003)

Nothing could be inferred about phylogeny-supported tracks for clade 2 (T. autazensis (T. papaveroi + T. naponica)). Only $T$. papaveroi formed a generalized track with $T$. limbata (track F). The species of this clade occur mainly along the Equator in Ecuador and Brazil and are further marked by the scarcity of geographical data.

Phylogeny-supported tracks were also characteristic of each Neotropical subregion. Track A is on the Parana subregion, track $\mathrm{D}$ is on the Parana and Chacoan subregion, tracks $\mathrm{G}, \mathrm{I}, \mathrm{L}, \mathrm{N}$ and $\mathrm{O}$ are on the Amazonian subregion and finally, track Q is into the Caribbean subregion (see Fig. 5). The largest number of phylogeny-supported tracks was established into the Amazonian subregion (Fig. 5). Given that these tracks corroborate historical identity for the concerned area, this confluence could sustain this subregion as having significant importance for Thecomyia's diversification.

Considering the biogeographical nodes, a total of eight were identified (Fig. 7). The defined biogeographic nodes and the generalized tracks involved in their identification, as well as their respective locations are shown in Table II.

The nodes identified herein may represent areas of great importance in the evolutionary context of the concerned taxa, particularly if they are supported by the taxa phylogenies. It means that node 2, for example, formed by the phylogenysupported tracks C and D (Fig. 7), may comprise species with a common history on Earth (Nihei \& Carvalho 2005). Similarly, node 1 comprises the supported track $\mathrm{C}$ and node 4 , track G. Node 5, track I, node 6, tracks I and L, node 7, track L and finally node 8 encompasses the supported track N (Fig. 7). 


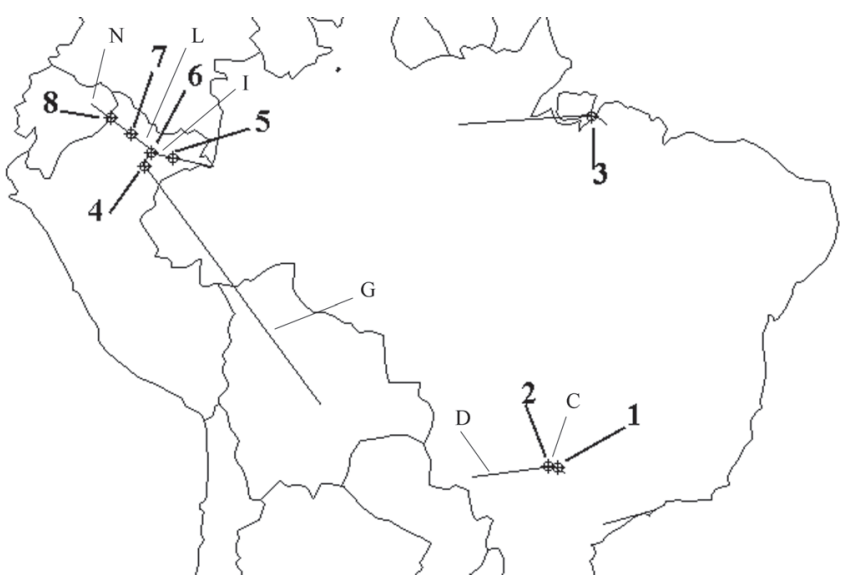

Fig. 7. Biogeographical nodes of the genus Thecomyia. The symbol $\phi$ indicates biogeographical nodes, and uppercase letters indicate phylogenysupported tracks.

Table II. Biogeographical nodes and their respective locations and generalized tracks intersected

\begin{tabular}{cccc}
\hline $\begin{array}{c}\text { Biogeographical } \\
\text { nodes }\end{array}$ & $\begin{array}{c}\text { Biogeographic } \\
\text { provinces }\end{array}$ & $\begin{array}{c}\text { Neotropical } \\
\text { subregion }\end{array}$ & $\begin{array}{c}\text { Generalized } \\
\text { tracks intersected }\end{array}$ \\
\hline 1 & Parana Forest & Parana & B and C \\
2 & Parana Forest & Parana & C and D \\
3 & Para & Amazonian & E and F \\
4 & Varzea & Amazonian & G and H \\
5 & Madeira & Amazonian & J and I \\
6 & Varzea & Amazonian & I, L and H \\
7 & Napo & Amazonian & L and M \\
8 & Napo & Amazonian & M and N \\
\hline
\end{tabular}

The obtained nodes may also be considered "relicts" of different ancestral biota coming into contact more recently (Crisci et al. 2003). In this way, they are particularly important as indicators of priority conservation areas due to the probable presence of biotic elements of different origins (Morrone \& Crisci 1992; Craw et al. 1999; Prevedello \& Carvalho 2006).

When comparing the distributional pattern of the genus Sepedonea (Pires et al. 2008), also studied by track analysis, with Thecomyia's distributional pattern, only the generalized track A, defined for Thecomyia, showed partial congruence with generalized tracks of Sepedonea ("p", "o" and "j") (Fig. 8). This occurs in the Atlantic Forest domain. There was no spatial congruence among biogeographical nodes of the two genera. The Parana subregion encompassing track A is spatially coincident with an area of endemism also indicated by other biogeographic studies focusing on several organisms other than Sciomyzidae (Cracraft 1985; Amorim \& Pires 1996; Camargo \& Pedro 2003; Carvalho et al. 2003; Nihei $\&$ Carvalho 2005). These overlapping patterns can also illustrate support for this area as historically important, not only for Thecomyia and Sepedonea species component of these tracks, but also for other unrelated organisms.

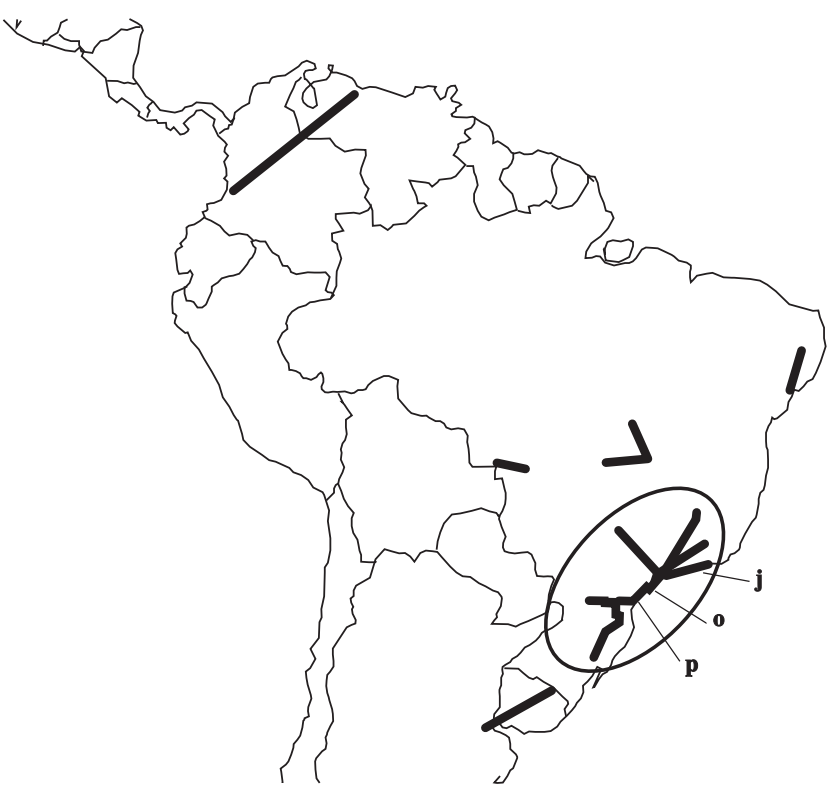

Fig. 8. Generalized tracks of Sepedonea (modified from Pires et al. 2008). The elipse indicates the area where confluence of Sepedonea generalized tracks occurs. Letters" $p$ ", "o" and "j" correspond to generalized tracks that are congruent with generalized track "A" of Thecomyia.

The individual tracks were also analyzed revealing additional historical information that had not been identified in the analysis of nodes and generalized tracks, as suggested by Nihei \& Carvalho (2005). The individual tracks corresponding to the species of clade 1 (T. tricuneata (T. longicornis ( $T$. chrysacra $+T$. signorelli))) were connected to one another, enabling the identification of one possible area of vicariance between the ancestor of the basal species of this clade ( $T$. tricuneata) and the remaining species (T. longicornis, $T$. chrysacra and T. signorelli) (Fig. 9). In fact, this clade is made up of one localized taxon and three taxa that have parts of their respective distributions that could be vicariant. It easily illustrates a widespread ancestor breaking up into four descendant taxa that have been partially dispersed into each others range, with the first bifurcation involving one localized descendent (T. tricuneata) and three that are widespread. This is the only point marked, given their identity with the phylogeny.

When analyzing the individual species tracks in clade 2 (T. autazensis (T. papaveroi $+T$. naponica)) and clade $3(T$. limbata (T. abercrombiei (T. lateralis $(T$. bonattoi $+\mathrm{T}$. mathisi)))) together with the phylogeny, two points of possible ancestral vicariance are noted between these clades (Fig. 10). One of the identified points corresponds exactly to the area of vicariance found in the previous analyses (Fig. 9). The other point is located on the northern extreme of Brazil, also in Amazonian domain, being supported by biogeographical node number 3 (Fig. 7). It is worth noting at this point that the term "nodes" also applies, in a broadly sense, to the intersection between individual tracks. For this reason, it is preferred to appoint these areas of overlap between distribution of clades as vicariance areas and not as "nodes", just to avoid confusion of terms. In fact, the areas of vicariance 


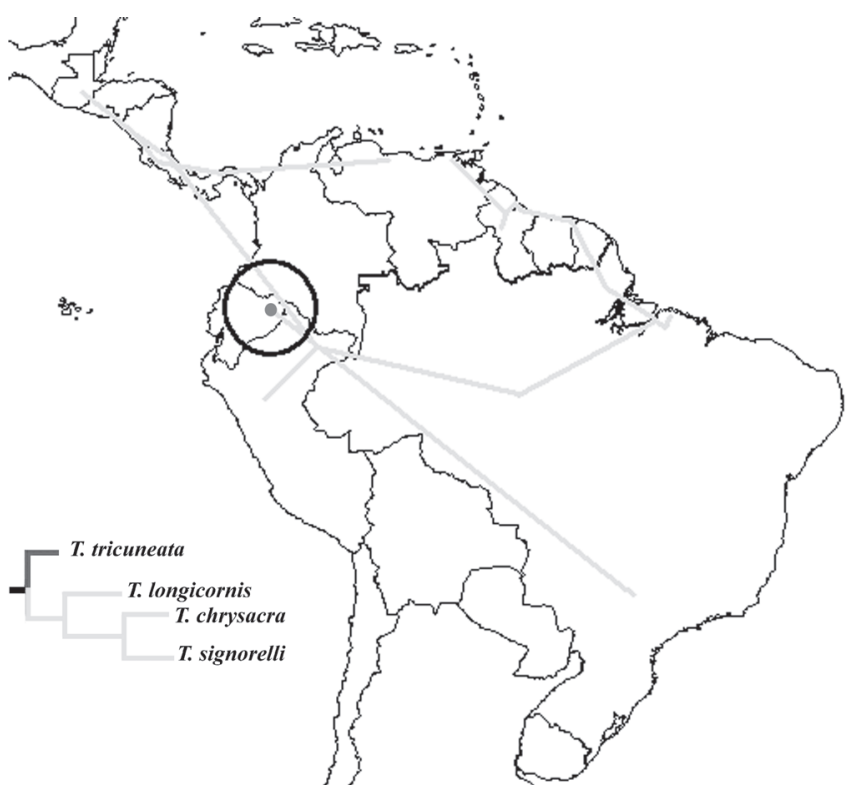

Fig. 9. Clade 1 of Thecomyia and the individual tracks for its species. The solid gray dot corresponds to the single locality known for T. tricuneata, and the light gray tracks to the distributions of T. longicornis, T. chrysacra and $T$. signorelli. The black circle indicates one possible area of vicariance between the ancestor of T. tricuneata and the remaining species of this clade.

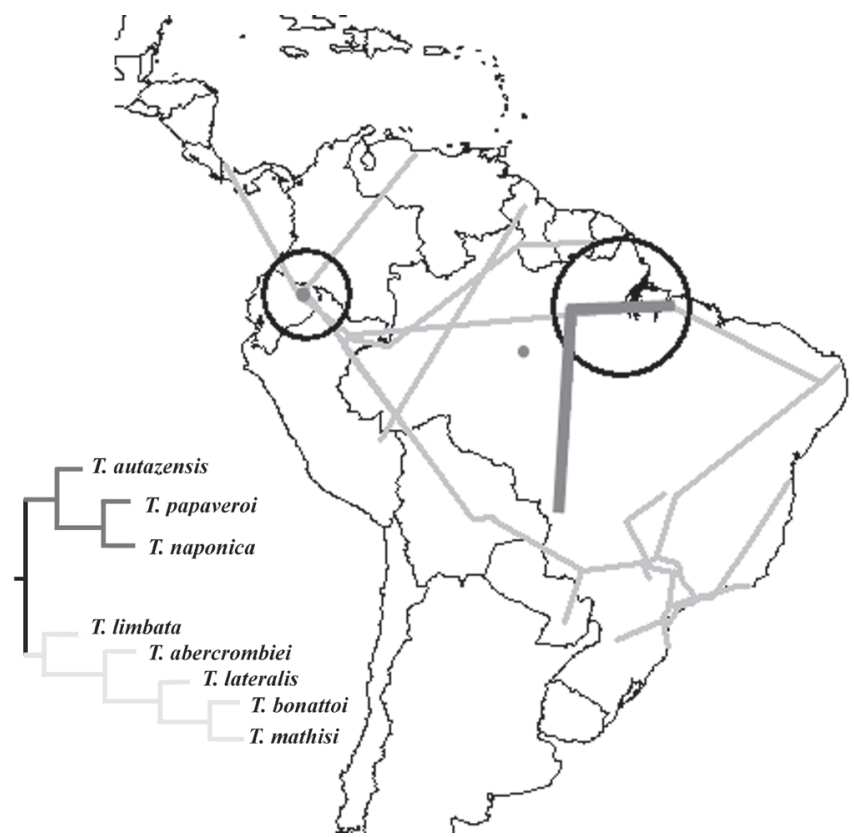

Fig. 10. Clades 2 and 3 and the individual tracks of their respective species. Dark gray and light gray tracks represent the distribution of species in clade 2 and clade 3, respectively. Black circles indicate two possible areas of vicariance between these two clades. The dark grey dots in Brazil and in Ecuador represent the single distributions known for T. autazensis and for T. naponica, respectively.

named here are nothing more than biogeographical nodes, which represent areas of differentiation when viewed in light of the phylogeny of the group and in light of the meaning of nodes as frontiers of differentiation.
Finally, as a vicariant result, it is expected that the panbiogeographic patterns of different taxa in the Neotropical region will overlap. Thus, the patterns resultant from the present study together with those of the Sepedonea track analysis provide an accumulative basis for further studies focusing on the comprehension of the neotropical evolution. In this way, several taxa, endemic of the area, need to be biogeographically analyzed planning an accumulation of patterns that helps uncover the history of the region. In the present study, we applied the panbiogeographic tool through track analysis and the results were analyzed based on the phylogenetic analysis of Thecomyia (Nihei \& Carvalho 2005; Pires et al. 2008). This association done between track analysis and phylogeny of the studied group is important as the generalized tracks and biogeographical nodes formed by phylogenetically-related species are historically more important than randomly related taxa, as shown by the correspondence proved by the phylogeny (Nihei \& Carvalho 2005).

\section{ACKNOWLEDGEMENTS}

ACP and LM (process 477024/2004-1) received financial support from Conselho Nacional de Desenvolvimento Científico (CNPq).

\section{REFERENCES}

Abercrombie, J. \& C. O. Berg. 1975. Natural history of Thecomyia limbata (Diptera: Sciomyzidae) from Brazil. Proceedings of the Entomological Society of Washington 77: 355-368.

Amorim, D. S. \& M. R. S. Pires. 1996. Neotropical biogeography and a method for maximum biodiversity estimation, p. 183-219. In: C. E. M. Bicudo \& N. A. Menezes (ed.). Biodiversity in Brazil, a first approach. São Paulo, CNPq, VI + 326p.

Camargo, J. M. F. \& S. R. M. Pedro. 2003. Meliponini neotropicais: O gênero Partamona Schwarz, 1939 (Hymenoptera, Apidae, Apinae) bionomia e biogeografia. Revista Brasileira de Entomologia 47: 311372 .

Carvalho, C. J. B. de; M. Bortolanza; M. C. Cardoso da Silva \& E. D. G. Soares. 2003. Distributional patterns of the Neotropical Muscidae (Diptera), p. 263-274. In: J. J. Morrone \& J. Llorente (ed.). Una perspectiva latinoamericana de la biogeografía. Mexico, Las Prensas de Ciencias, Facultad de Ciencias, Universidad Autónoma de México, 307p.

Contreas-Medina, R; I. Luna-Vega \& J. J. Morrone. 2001. Conceptos biogeográficos. Elementos: ciencia y cultura 8: 33-37.

Cracraft, J. 1985. Historical biogeography and patterns of differentiation within the South American avifauna: Areas of endemism, p. 49-84. In: P. A. Buckley, M. S. Foster, E. S. Morton, R. S. Ridgely \& F. G. Buckley (ed.). Neotropical ornithology. Washington, D.C., Ornithological Monographs 36, The American Ornithologists' Union, XII + 1041p.

Craw, R. C.; J. R. Grehan \& M. J. Heads. 1999. Panbiogeography: Tracking the history of life. New York, Oxford University Press, 229 p.

Crisci, J. V.; L. Katinas \& P. Posadas. 2003. Historical biogeography: An introduction. Cambridge, Harvard University Press, $250 \mathrm{p}$.

Croizat, L. 1958. Panbiogeography. Caracas, Venezuela, Published by the author.

Croizat, L. 1964. Space, time, form: The biological synthesis. Caracas, Venezuela, Published by the author.

ESRI (Environmental Systems Research Institute). 1998. ArcView GIS 3.2. Grehan, J. R. 1993. Conservation biogeography and the biodiversity crisis: A global problem in space/time. Biodiversity Letters 1: 134-140. 
Harold, A. S. \& R. D. Mooi. 1994. Areas of endemism: definition and recognition criteria. Systematic Biology 43: 261-266.

Heads, M. J. 2004. What is a node? Journal of Biogeography 31: 1883-1891.

Knutson, L. V. \& C. J. B. de Carvalho. 1989. Seasonal distribution of a relatively rare and a relatively common species of Thecomyia at Belém, Pará, Brazil (Diptera, Sciomyzidae). Memórias do Instituto Oswaldo Cruz 84: 287-289.

Marinoni, L. \& W. N. Mathis. 2000. Cladistic analysis of Sciomyzidae Fallén, 1820 (Diptera). Proceedings of the Biological Society of Washington 113: 162-209.

Marinoni, L.; G. C. Steyskal \& L. Knutson. 2003. Revision and cladistic analysis of the Neotropical genus Thecomyia Perty (Diptera: Sciomyzidae). Zootaxa 191: 1-36

Morrone, J. J. 2001a. Homology, biogeography and areas of endemism. Diversity and Distributions 7: 297-300.

Morrone, J. J. 2001b. Biogeografia de América Latina y el Caribe. M \& T-Manuales \& Tesis SEA. Zaragoza, $148 \mathrm{p}$.

Morrone, J. J. 2003. Homología biogeográfica primaria de la família Trichodactylidae (Crustacea: Decapoda), p. 241"245. In: J. J. Morrone \& J. Llorente (ed.). Una perspectiva latinoamericana de la Biogeografía. Mexico, Las Prensas de Ciencias, Facultad de Ciencias, Universidad Autónoma de México, 307p.

Morrone, J. J. 2004. Panbiogeografia, componentes bióticos y zonas de transición. Revista Brasileira de Entomologia 48: 149-162.

Morrone, J. J. 2005. Cladistic biogeography: identity and place. Journal of Biogeography 32: 1281-1286.

Morrone, J. J. 2006. Biogeographic areas and transition zones of Latin America and the Caribbean islands based on panbiogeographic and cladistic analysis of the entomofauna. Annual Review of Entomology 51: 467-494.

Morrone, J. J. \& J. V. Crisci. 1992. Aplicación de metodos filogenéticos y panbiogeográficos en la conservación de la diversidad biológica.
Evolución Biológica 6: 53-66.

Morrone, J. J. \& J. V. Crisci. 1995. Historical biogeography: Introduction to methods. Annual Review of Ecology and Systematics 26: 373 401

Neff, S. E. \& C. O. Berg. 1966. Biology and immature stages of malacophagous Diptera of the genus Sepedon (Sciomyzidae). Bulletin of Agricultural Experiment Station, Virginia Polytechnic Institute 556: $1-113$.

Nihei, S. S. \& C. J. B. de Carvalho. 2005. Distributional patterns of the Neotropical fly genus Polietina Schnabl \& Dziedzicki (Diptera, Muscidae): A phylogeny-supported analysis using panbiogeographic tools. Papéis Avulsos de Zoologia 45: 313-326.

Nihei, S. S. \& C. J. B. de Carvalho. 2007. Systematics and biogeography of Polietina Schnabl \& Dziedzicki (Diptera, Muscidae): Neotropical area relationships and Amazonia as a composite area. Systematic Entomology 32: 477-501.

Pires, A. C.; L. Marinoni \& C. J. B. de Carvalho. 2008. Track analysis of the Neotropical genus Sepedonea Steyskal (Diptera: Sciomyzidae): a proposal based on the phylogenetic analysis of its species. Zootaxa 1716: $21-34$

Platnick, N. I. 1991. On areas of endemism. Australian Systematic Botany 4: 11-12.

Prevedello, J. A. \& C. J. B. de Carvalho. 2006. Conservação do Cerrado brasileiro: O método pan-biogeográfico como ferramenta para a seleção de áreas prioritárias. Natureza \& Conservação 4: 39-57.

Rede SpeciesLink. 2008. Sistema de Informação Distribuído para Coleções Biológicas: a Integração do Species Analyst e do SinBiota (FAPESP). Available from: http://splink.cria.org.br/centralized_search (accessed 8 May 2008).

Sigrist, M. S. \& C. J. B. de Carvalho. 2009. Historical relationships among areas of endemism in the tropical South America using Brooks Parsimony Analysis (BPA). Biota Neotropica 9: 1-12. 
Appendix. Geographical data of Thecomyia used in the biogeographic analysis (within brackets, longitude and latitude, respectively).

Thecomyia longicornis: GUYANA: Kaieteur (-59.49, 5.14), Essequibo river (-58.41, 6.88), Mazaruni (-59.22, 6.23), Blairmont (-57.58, 6.28), Cuba (58.22, 6.50); VENEZUELA: Caripito (-63.10, 10.11); COSTA RICA: Golfito (-84.05, 10.64); NICARAGUA: Chinandega (-87.13, 12.63); SURINAME: Moengo (-54.40, 5.61); BRAZIL: Amapá: Serra do navio (-52.03, 0.88), Porto Platon (-51.46, 0.72); Pará: Santana (-47.74, -2.04), Xingú river $(-52.37,-3.65)$, Belém/Mocambo $(-48.48,-1.47)$, Airi $(-58.29,-6.90)$, Utinga $(-48.46,-1.40)$, Peixe boi $(-47.32,-1.2)$; PERU: San Martin: Juanjui (-76.74, -7.17); Loreto: Pucallpa (-72.92, -3.46).

Thecomyia lateralis: GUYANA: Moco Moco river (-59.65, 3.30); SURINAME: Anapaike (-54.03, 3.43); BRAZIL: Amazonas: Benjamin Constant (70.03, -4.38); Bahia: Itabuna (-39.28, -14.79); Minas Gerais: Andes (-42.08, -19.15), Mato Grosso: Maracajú (-55.15, -21.63); Goiás: Corumbá $(-48.80,-15.8)$, Jataí $(-51.72,-17.88)$; São Paulo: Tamoio/Jacaré river $(-48.17,-21.79)$, Magda $(-50.23,-20.64)$, Boracéia/Salesópolis $(-45.87,-$ 23.63), Iporanga (-48.59, -24.59), Avanhadava (-49.95, -21.46), Araçatuba/Córrego Azul (-50.53, -21.08), Araçatuba/Jacarecatinga river (-50.43, -21.21), Ilha dos Búzios (-45.14, -23.81); Paraná: Morretes/Sapitanduva (-48.84, -25.48); Santa Catarina: Florianópolis (-48.55, -27.60); PERU: Iquitos $(-73.19,-3.75)$; Loreto: Ucayali river $(-73.47,-4.51)$; BOLÍVIA: Santa Cruz: Provincia Andrés Ibañez/Potrerillo del Guenda (-63.46, 17.71); Pozo del Tigre $(-61.98,-17.61)$.

Thecomyia limbata: PANAMA: Guabito (-82.61, 9.49); VENEZUELA: Carabobo: Valencia (-68.03, 10.18); BRAZIL: Pará: Belém/Mocambo (-48.48, -1.47), Utinga (-48.46,-1.40); Rio Grande do Norte: Macahyba (-35.35, -5.85); Paraíba: Areia (-36.83, -7.25); Distrito Federal/Núcleo Bandeirantes (-47.97, -15.87); Mato Grosso: Maracajú (-55.15,-21.63); Rio de Janeiro: Rio de Janeiro (-43.23, -22.96), Jacarepaguá (-43.35, -22.94), Araruama (-42.34, -22.87); São Paulo: São Vicente/Bitaru park (-46.39, -23.97), Juquiá (-47.64, -24.32); Itanhaém (-46.79, -24.18), Araçatuba/Jacarecatinga river $(-50.43,-21.21)$, Araçatuba/Córrego Azul (-50.53, -21.08), Ribeirão Preto/Tamanduá river $(-47.81,-21.18)$, Rio Claro (-47.56, -22.41), Vera Cruz (-49.83, -22.23), Onda verde (-49.30, -20.62); Paraná: Praia de Leste/Matinhos (-48.54, -25.83), Paranaguá (-48.51, -25.52); Morretes (48.84, -25.48); Santa Catarina: Nova Teutônia (-52.40, -27.05), Antonina (-48.71, -25.43); Goiás: Campinas (-47.06, -22.91); ECUADOR: Lago Agrio (-76.8, -0.75); PERU: Loreto: Pucallpa (-72.92, -3.46); PARAGUAY: Villa Rica (-56.43, -25.75).

Thecomyia abercrombiei: GUYANA: Mazaruni/Portaro Dictrict/Takutu Mountains (-59.5, 6.15); PERU: Madre de Dios (-70.56, -11.65).

Thecomyia autazensis: BRAZIL: Amazonas: Autaz river (-59.93, -4.41)

Thecomyia bonattoi: PANAMA: Corazal $(-82.33,8.66)$.

Thecomyia chrysacra:NICARAGUA: Managua (-86.27, 12.15); GUATEMALA: La Providencia (-89.98, 15.00); COSTA RICA: Higuitto/San Mateo/ província del Alajuela (-84.55, 9.95); PANAMA: Gamboa (-79.70, 9.12), Juan Mina (-79.65, 9.17), Lago Alhajuela (-79.58, 9.24); VENEZUELA: Carabobo: Yuma $(-67.70,10.10)$.

Thecomyia mathisi: ECUADOR: Prt. Orllna/Tiputini river (-76.15, -0.64); BOLIVIA: Andrés Ibañes/Potrerillo del Guenda (-63.46, -17.71).

Thecomyia naponica: ECUADOR: Napo river $(-76.31,-0.70)$.

Thecomyia papaveroi: BRAZIL: Pará: Oriximina (-55.86, -1.76), Belém/Mocambo (-48.48, -1.47), Northeast of Belém/Utinga (-48.46, -1.40); Mato Grosso: Transpantaneira highway $(-56.84,-16.83)$.

Thecomyia signorelli: BRAZIL: São Paulo: Avanhadava/Barra Mansa (-49.95, -21.46), Araçatuba/Córrego Azul (-50.53, -21.08); ECUADOR: Napo river $(-76.31,-0.70)$.

Thecomyia tricuneata: ECUADOR: Napo river $(-76.31,-0.70)$. 